\title{
ADVANCED SIGNAL PROCESSING METHODS FOR INSPECTION OF AIRCRAFT STRUCTURAL MATERIALS
}

\author{
Iuliia Lysenko $^{1} \cdot$ ORCID: 0000-0001-9110-6684, \\ Volodymyr Eremenko ${ }^{1}$ - ORCID: 0000-0002-4330-7518, \\ Yurii Kuts $^{1}$ • ORCID: 0000-0002-8493-9474, \\ Anatoliy Protasov ${ }^{1} \bullet$ ORCID: 0000-0002-2965-3334, \\ Valentin Uchanin ${ }^{2} \bullet$ ORCID: 0000-0001-9664-2101. \\ ${ }^{1}$ Technical University of Ukraine "Igor Sikorsky Kyiv Polytechnic Institute”, \\ Prosp. Peremohy 37, Kyiv, Ukraine, 03056 \\ ${ }^{2}$ Karpenko Physico-Mechanical Institute of the National Academy of Sciences of Ukraine, \\ Naukova St. 5, Lviv, Ukraine, 79060 \\ j.lysenko@kpi.ua
}

\begin{abstract}
Aircraft, their assemblies, and units must provide high durability and reliability, and maintain mechanical and technological characteristics throughout the life span of the aircraft. Different elements of aircraft structures work under mechanical loads, over a wide temperature range, with varying degrees of exposure to corrosive environments. Aircraft structural materials have a variation in the characteristics values and require the various testing methods for their inspection.

In many NDT methods applied in aviation materials testing, signals that could be represented by a narrowband processes model are used. Known methods of their processing are focused on determining and analyzing the signals amplitude characteristics, but the information resource contained in phase characteristics is not used.

In the article, the methodology for signal processing and determining phase characteristics in the time domain are discussed. It is based on the combination of the discrete Hilbert transform and the deterministic and statistical methods of the phase measurement. There are given examples of the application of the methodology for pulsed eddy current testing of electrically conductive materials and products, ultrasonic thickness measurement of products made of materials have significant ultrasonic attenuation, the realization impulse variant of acoustic impedance flaw detection of products made of composite materials. The examples have shown that the proposed signal processing methodology enables to determine new information parameters and signal characteristics for the industry, and extend the scope of known NDT methods.
\end{abstract}

Keywords: signal processing methodology, signal characteristics, information parameters, aviation materials testing. 


\section{INTRODUCTION}

Aircraft single parts and units have to have the properties that keep high durability and reliability for all the entire construct. The mechanical, physical, technological, and operational properties of aircraft element materials must remain unchanged throughout the lifetime of the aircraft. Different elements of aircraft structures operate under different types of mechanical stress, over a wide temperature range, at varying degrees of exposure to corrosive environments and have different geometric characteristics. This requires the use of aircraft structures made from different materials [1] - alloys (aluminum, titanium, magnesium, copper), steels (carbon, alloyed structural, heat resistant), composite materials (polymeric, metal-polymeric, metallic), etc. Significant variation in the values of physicomechanical and electrical parameters and characteristics of aircraft structural materials causes the use of various physical methods and modes of testing.

The inspection results depend not only on the physical testing method and its hardware implementation but also on the algorithm of signal processing, the choice of the most informative parameters and signals characteristics. The high testing quality of materials and products can be ensured if the balance between the hardware and software-algorithmic components of the non-destructive testing (NDT) tools is ensured.

The signals that can be represented by the model of narrowband processes are used for many NDT methods that are actively applied for the aviation materials testing, in particular, eddy current $[1,2,3]$, ultrasonic [1, 4], acoustic $[1,5]$. The informative characteristics are the signal envelope, frequency, phase, and signal spectra $[6,7]$. These characteristics are time dependence and functionally or correlatively related to the parameters and characteristics of the materials and products. Most of the known methods of processing such signals include the determination and analysis of their amplitude characteristics. Such methods are relatively simple to implement, but the information resource contained in signals phase characteristics remains incompletely used.

In the article, the methodology of processing NDT signals and determining their phase characteristics in the time domain is discussed. The methodology is based on the combination of the Hilbert signals discrete transformation capabilities and the methods of deterministic and statistical phase measurement.

\section{THEORETICAL PART}

Narrowband signals in the NDT are generally represented as a model of the form:

$u\left(t, \bar{p}_{r}\right)=A\left(t, \bar{p}_{r}\right) \cos \left[\Phi\left(t, \bar{p}_{r}\right)\right]$

where $t$ - time, $\bar{p}_{r}$ - parameters vector of the testing material and product, $A\left(t, \bar{p}_{r}\right), \Phi\left(t, \bar{p}_{r}\right)-$ the signal envelope and its phase performance, respectively. There is a Hilbert transform [6, 7], which makes it possible to uniquely represent the cyclically time-varying function (1) due to its fast phase $\Phi\left(t, \bar{p}_{r}\right)$ and much slower amplitude $A\left(t, \bar{p}_{r}\right)$ characteristics.

In the NDT tools the signal processing of the form (1) is carried out in digital form [7]. In this case the problem of determining the discrete characteristics of the signals is provided by the next approach. The array $S=\left\{t_{1}, t_{2}, \ldots, t_{j}, \ldots, t_{n}\right\}$ is plotted at the observation interval $\left[0, T_{O}\right]$ and the set of array elements ordered, that is $0 \leq t_{1} \leq t_{2}<\ldots<t_{j}<\ldots<t_{n} \leq T_{O}$. The elements are spaced evenly and form an arithmetic progression with step $\Delta t=t_{j}-t_{j-1}$. A sequence of signal values $u\left(t_{j}, \bar{p}_{r}\right)=u[j]$ is set for $S$, this sequence is an image of a continuous signal (1). The analysis interval contains several signal periods (1), viz $\Phi\left(T_{O}, \bar{p}_{r}\right)-\Phi\left(0, \bar{p}_{r}\right) \gg>2 \pi$. The sequence $S$ is the domain of definition of the studied 
function, and the sequence $\{u[j], j=\overline{1, n}\}$ is their domain of values, where $n=\left[T_{O} / \Delta t\right]^{+},[\cdot]^{+}$is the designation of an integer part of the number.

For the $\{u[j], j=\overline{1, n}\}$ sequence, there is a discrete transformation with the Hilbert core (discrete Hilbert transformation - DHT) $[6,7]$, which allows to obtain the Hilbert image $u_{\mathrm{H}}[j]$ of that sequence. On this basis, the discrete amplitude $A[j]$, phase $\varphi_{2 \pi}[j] \in[0,2 \pi)$, unwrapped phase $\Phi[j]$ and frequency $f[j]$ signal characteristics are determined [4]:

$$
\begin{aligned}
& A[j]=\sqrt{u^{2}[j]+u_{H}^{2}[j]}, j=\overline{1, n}, \\
& \varphi_{2 \pi}[j]=\operatorname{arctg} \frac{u_{H}[j]}{u[j]}+\frac{\pi}{2}\left\{2-\operatorname{sign} u_{H}[j][1+\operatorname{sign} u[j]]\right\}=\mathbf{L}\left[u[j], u_{H}[j]\right], j=\overline{1, n}, \\
& \Phi[j]=\varphi_{2 \pi}[j]+2 \pi \mathbf{K}\left[u[j], u_{H}[j]\right], j=\overline{1, n}, \\
& f[j]=\frac{1}{2 \pi} \cdot \frac{\left(\varphi_{2 \pi}[j]-\varphi_{2 \pi}[j-1]\right) \bmod 2 \pi}{\Delta t}, j=\overline{2, n},
\end{aligned}
$$

where $\mathrm{K}[]$ - the operator that eliminates phase jumps at the transition points from $2 \pi$ to 0 .

Therefore, the DHT allows obtaining the statistics sets $A[j], \varphi_{2 \pi}[j], \Phi[j]$ and $f[j]$. The phase shifts of the signal (1) relative to the reference sine wave signal with frequency:

$$
f_{0}=\frac{\Phi\left[n T_{d}\right]-\Phi\left[T_{d}\right]}{2 \pi(n-1) T_{d}}
$$

are defined as the differences between the unwrapped phase characteristics of the signal (1) and the reference signal $u[j]=\cos \left(2 \pi f_{0} T_{d} j\right)$ :

$$
\varphi[j]=\left(\Phi[j]-2 \pi f_{0} T_{d} j\right), j=\overline{1, n} .
$$

Using the sampling data $\theta=\left\{\Delta \varphi_{j}, j=\overline{1, n}, \Delta \varphi_{j} \in[0,2 \pi)\right\}$ creates the basis for the application of statistical analysis methods of angular data $[8,9]$ during the analysis of NDT signals. These data are accepted to be displayed on a circle of a single radius by points or radius vectors in a Cartesian rectangular coordinate system xOy (Fig. 1).

Averaging of the sampling data on a circle produces a vector of a certain length. The sample circular mean of the phase shift $\varphi_{\mathrm{CP}}=L(S, C)$ is the vector argument, which is formed by the sum of the unit vectors $\overrightarrow{O P}_{1}, \ldots, \overrightarrow{O P}_{n}$. For example, for $n=3$ (Fig. 1b) the total vector is $\overrightarrow{O P}=\sum_{i=1}^{3} \overrightarrow{O P}_{i}$ and has $\left(\sum_{i=1}^{3} \cos \varphi_{i}, \sum_{i=1}^{3} \sin \varphi_{i}\right)$
coordinates. 
a)
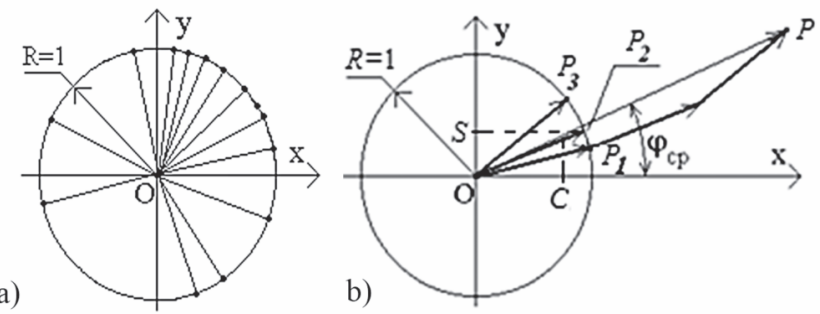

Fig. 1. Graphical representation of the results of obtained signals phase shifts on a circle

Statistical characteristics determined from sampling data $\theta$ include sampling trigonometric moments, circular mean, circular variance, circular median, resultant vector length, etc. Their definitions are given in Tab. 1.

Table 1. Circular statistics determined by sampling data $\theta$ and volume $n=3$.

\begin{tabular}{|l|l|}
\hline Name of circular statistical characteristic & Definition, formula \\
\hline Sampling circular mean & $\varphi_{c}=\operatorname{arctg} \frac{S}{C}+\frac{\pi}{2}\left\{2-(\operatorname{sign} S) \times[1+\operatorname{sign} C] \quad C=\frac{1}{n} \sum_{j=1}^{n} \cos \varphi_{j} ; S=\frac{1}{n} \sum_{j=1}^{n} \sin \varphi_{j}\right.$ \\
\hline Sampling length of the resultant vector & $r=\sqrt{C^{2}+S^{2}}$ \\
\hline Sampling circular variance & $V=1-r$ \\
\hline Sampling circular mode & $\begin{array}{l}\text { The angle which corresponds to the point of the circle where } \\
\text { the maximum concentration of sampling values } \Delta \varphi[j] \text { is observed }\end{array}$ \\
\hline Sampling circular median & $\begin{array}{l}\text { The angle to which the point of the circle } P \text { corresponds in case if } \\
\text { the diameter } P Q \text { divides the value of sampling value } \Delta \varphi[j] \text { in half and } \\
\text { the maximum concentration of the sampling is observed around } P\end{array}$ \\
\hline $\begin{array}{l}\text { Sampling trigonometric moment of } \\
\text { order } u \text { relatively to the direction } \alpha \\
(u \text { is an integer) }\end{array}$ & $\begin{array}{l}T_{u}(\alpha)=\frac{1}{n} \sum_{j=1}^{n} e^{i u\left(\varphi_{j}-\alpha\right)}=a_{u}(\alpha)+i b_{u}(\alpha)=r_{u}(\alpha) e^{i m_{u}(\alpha) ; u=0,1,2, \ldots} \\
a_{u}(\alpha)=\frac{1}{n} \sum_{j=1}^{n} \cos \left[u\left(\varphi_{j}-\alpha\right)\right]=a_{u}(0) \cos (u \alpha)+b_{u}(0) \sin (u \alpha) ; \\
b_{u}(\alpha)=\frac{1}{n} \sum_{j=1}^{n} \sin \left[u\left(\varphi_{j}-\alpha\right)\right]=-a_{u}(0) \sin (u \alpha)+b_{u}(0) \cos (u \alpha) ; \\
r_{u}(\alpha)=\sqrt{a_{u}^{2}(\alpha)+b_{u}^{2}(\alpha)}=\sqrt{a_{u}^{2}(0)+b_{u}^{2}(0)}=r_{u}(0) ; \\
m_{u}(\alpha)=m_{u}(0)-u \alpha .\end{array}$ \\
\hline
\end{tabular}

\section{APPLICATION OF PHASE CHARACTERISTIC OF THE SIGNAL IN DIFFERENT NDT METHODS}

\section{Pulsed eddy current testing of conducting materials and products}

Eddy current testing (ET) with pulsed excitation along with digital processing of information signals based on DHT significantly complement the known methods due to the possibility of analysis of such signals parameters as the frequency of natural oscillations, the peak amplitude, the signal decrement and the time position of the signal characteristic points [10]. Using the mentioned characteristics of the eddy current transducer (ECT) signals as a function of the depth of the cracks, it is possible to extend the functionality of flaw detection by estimating the depth of the cracks. For this purpose, the experimental researches of 
pulsed ET signals have been performed to the testing of the plate made from aluminum alloy AD31T5 (Fig. 2, b) with cracks: depth of $0.1 \mathrm{~mm}$ to $3 \mathrm{~mm}$, opening to $1 \mathrm{~mm}$. Plate scanning has been performed with a $1 \mathrm{~mm}$ step using a (laid-on differential ECT).

The mathematical model of the ECT information signal has the form (Fig. 2, a):

$u_{e c t}(t, h)=U_{m} e^{-\alpha(h) \cdot t} \cdot \sin [2 \pi \cdot f(h) \cdot t+v]+u_{n}(t), t \in\left(t_{1}, t_{2}\right)$,

where $U_{m}$ - the amplitude value of the ECT signal, $\alpha(h)$ - signal decrement, $f(h)$ - the frequency of natural oscillations, $t$ - time, $\left(t_{1}, t_{2}\right)$ - the analysis time interval of the ECT signal, $u_{n}(t)$ - noise component of the signal, $v-$ initial phase, $v=\operatorname{arctg}\left(\alpha / \omega_{0}\right)$.
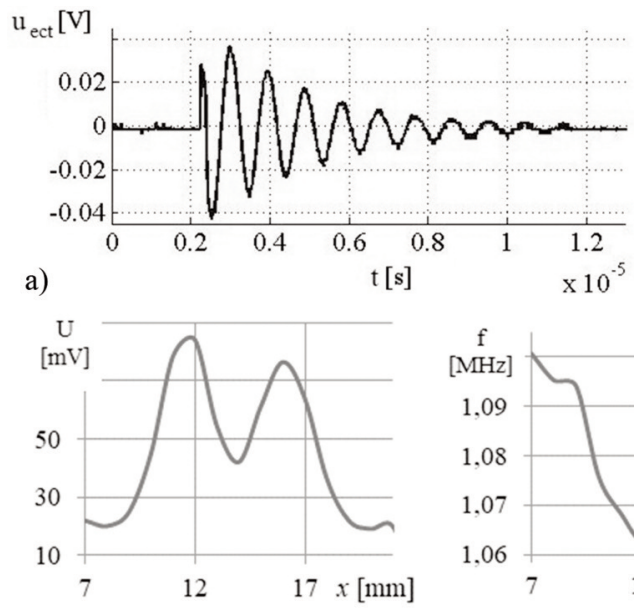

c)

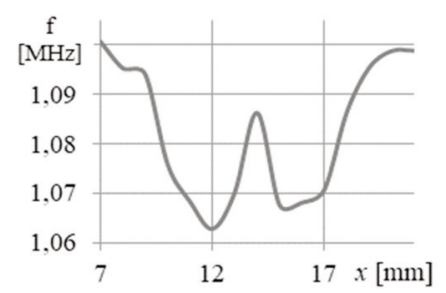

d)

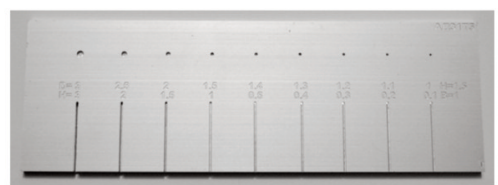

b)

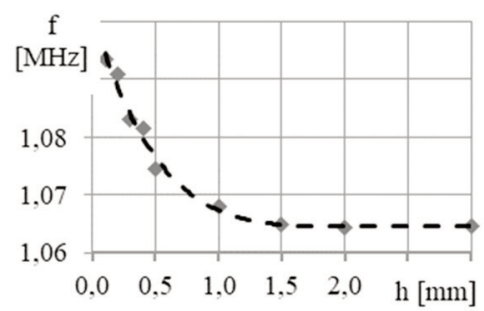

e)

Fig. 2. Fragment of ECT signals (a), picture of the testing object (b), distribution of the peak amplitude (c) and natural oscillations frequency of ECT signal (d) along the defective area, the dependence of the frequencies of ECT signals on the depth of the cracks (e).

To analyze the effect of sample characteristics on the ECT signal, the frequencies $f(h)$ of the signals have been used as informative parameters. It was determined the averaged frequencies of the ECT signals using phase characteristic of the signals according to formula (6). The obtained experimental data and results are presented in Fig. 2.

Using the ECT signals amplitude and frequency, it is possible to extend the functionality of flaw detection to estimate the depth of the cracks. The application of the proposed method for determining the signals phase characteristic can reduce the error in the calculation of the ECT signal frequency and increase the estimation accuracy of the testing object parameters in several times.

\section{Ultrasonic testing of the thickness of the products in case of significant signal attenuation in the material}

In the case of structural materials testing with significant ultrasonic attenuation, there is a problem of detecting ultrasonic pulse signals represented as a harmonic signal with valid information and the considerable noise. This problem is effectively solved by determining the discrete phase characteristics of the signals and their subsequent statistical analysis. Such a method is proposed and investigated in $[4,11]$. 
Pulse-echo method of ultrasonic thickness measurement (UTM) is based on the determination of the time delay $\tau_{d}$ required for the propagation of the ultrasonic signal inside the testing object [12]. The testing object thickness is defined as $h=0,5 \cdot c \cdot \tau_{d}$ if the propagation velocity $c$ of a dilatational ultrasonic wave in two directions between the surface and the bottom of the object is known. The value of $\tau_{d}$ is usually estimated by the time interval between the envelopes of the two back wall ultrasonic signals. This method is very sensitive to noise.

Determining the phase characteristics of the echo signals in conjunction with the statistical methods of processing these characteristics, allows detecting UTM signals at a signal/noise ratio $(\mathrm{s} / \mathrm{n})$ close to one or less.

The proposed method of UTM is based on following actions: formation an ultrasonic initial pulse indication, entering it into the testing object, receiving the signal after its propagation through the object and reflection from the opposite side (back wall), determining the phase characteristics of the reflected signals (echo), calculating the phase difference between the echoes and initial signals, providing its sliding window processing, calculating the length values of the resultant vector $r$, which are selected by the window with the aperture $M_{W}$, as a function of time, the maximums of which determine $\tau_{d}$. In the case of obtaining a sequence of attenuating echo signals, the thickness of the product is calculated by the following formula:

$h=0,5 \cdot \tau_{1, k} \cdot c /(k-1)$,

where $\tau_{1 k}$ - the time interval between the first and $k$ echo signals. According to this, the root-mean-square value of the time interval quantization error decreases by $\sqrt{k-1}$ times.

It has been used the stainless steel sample with $17.8 \mathrm{~mm}$ thick in the experiments. The frequency of the filling signal is $2.23 \mathrm{MHz}$. The obtained experimental data and calculation results are presented in Fig. 3, a-c, and the photo of the sample - Fig. 3, d.

a) 0
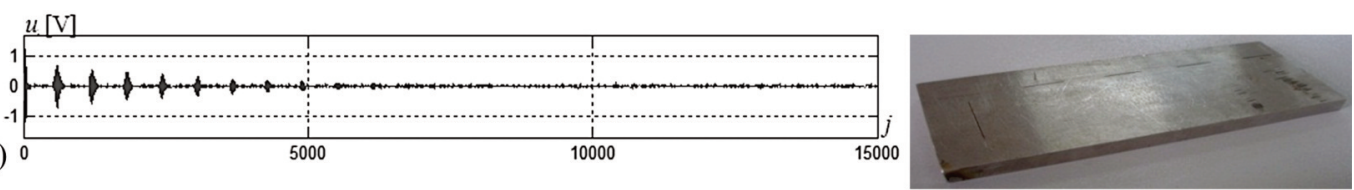

d)
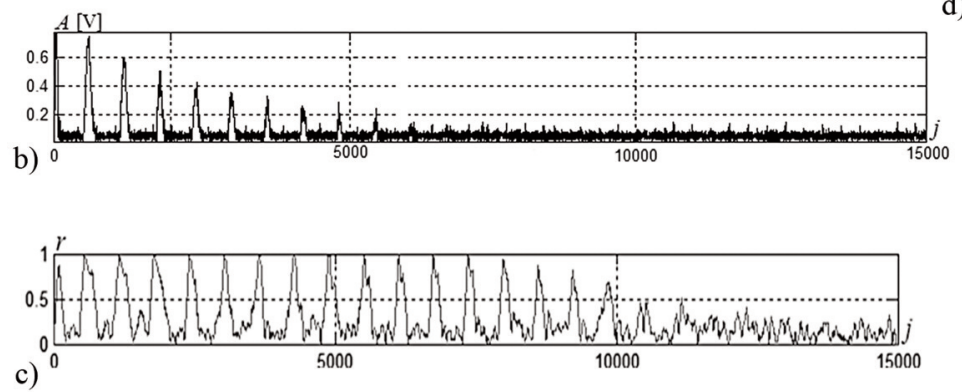

Fig. 3. The graphs of experimental results: a) sequence $u[j]$; b) sequence $A[j]$; c) sequence $r\left[j, M_{W}\right]$;

d) photo of the sample

In this experiment, the echo signals on the background of the noise are difficult to distinguish using the signal envelope $A[j]$ after the tenth pulse. However, the graph of the sequence $r\left[j, M_{W}\right]$ indicates that 18 echo signals are easily detected in this experiment. The ratio $s / \mathrm{n}$ is -1 for pulse number $i=8$. The attenuation coefficient of the sample material at a frequency of $2.5 \mathrm{MHz}$ is $2.2 \mathrm{~Np} / \mathrm{m}$, and 
the longitudinal ultrasonic wave velocity is $5723 \mathrm{~m} / \mathrm{s}$. The measured value of the time interval is $104.7 \mu \mathrm{s}$. Taking into account these data, the calculation of the sample thickness according to (9) gives the value $h=17.63 \mathrm{~mm}$, and the absolute error of measurement the sample thickness is $0.17 \mathrm{~mm}$ that is less than $1 \%$.

\section{Pulse acoustic impedance flaw inspection of composite products}

It is known the variation of the mechanical impedance of the testing zone leads to a change in the envelope, frequency, and phase of the impedance transducer informative signal $[13,14]$. Experimental research, that was held using a honeycomb sample with artificially created defects like a violation of structure, was conducted to confirm the possibility of using the signal phase characteristics (3), (4). Specifications of the sample: thickness - $20 \mathrm{~mm}$, filler type PSP-1-2,5 skin plate based on carbon fiber ELUR-P-0,1 and glue VK 41. The defect was presented by the area of disconnection between the skin plate and the honeycomb filler. The honeycomb skin plate from the defect side had no visual signs of damage; the skin plate from the opposite side was restored by gluing a patch made of similar carbon fiber. The frequency (5), phase (3), and unwrapped phase (4) characteristics of the impedance transducer signal were used as informative parameters. The obtained experimental data and calculation results are presented in Fig.4, a-b, and the photo of the sample - Fig. 4, c.
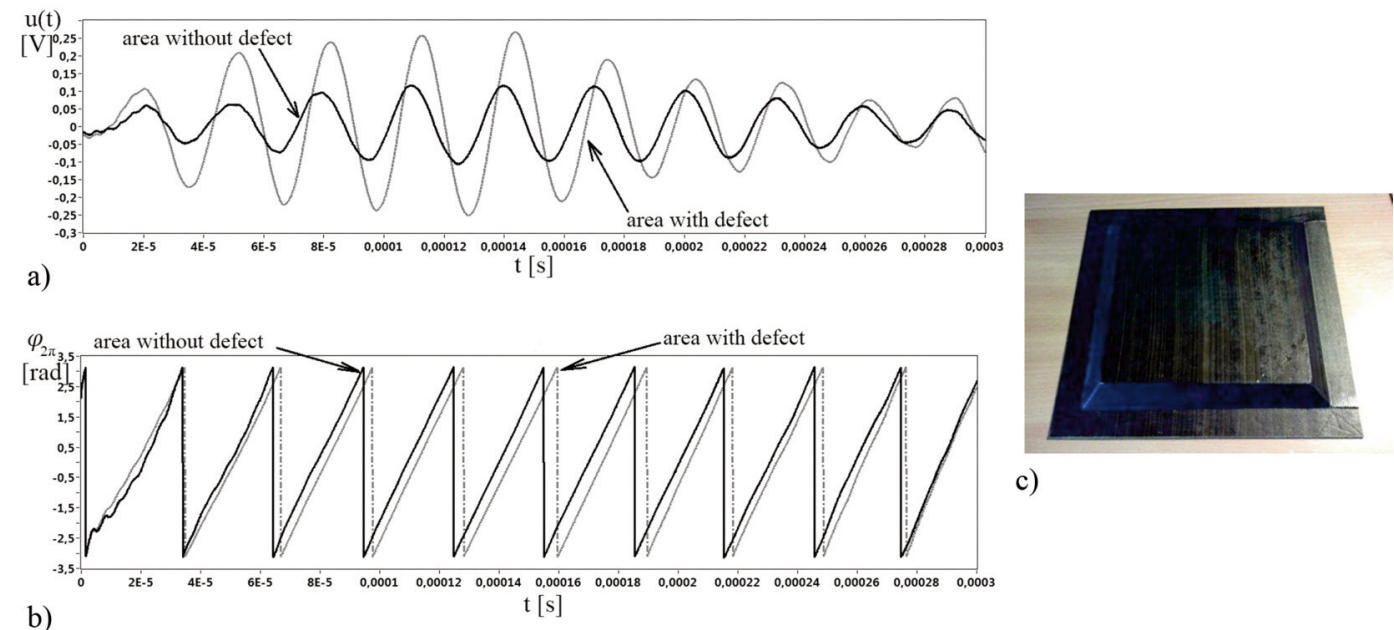

Fig. 4. Fragment of impedance transducer signals (a), its phase characteristics (b) from sample's areas with the defect and without, and photo of the testing sample (c)

The integral parameter proved to be most effective for detecting defects and assessing the damage degree of the sample. It is calculated by the unwrapped phase characteristic:

$$
F b=\int_{t_{1}}^{t_{2}}\left[\Phi_{2}(t)-\Phi_{1}(t)\right] d t,
$$

where $\Phi_{1}(t), \Phi_{2}(t)$ - unwrapped phase characteristics from the sample's areas with the defect and without, $t_{1}, t_{2}$ - the limits of integration. 
The probability estimation of detecting defects has been performed experimentally. For this purpose, a series of tests with a volume of 100 were performed. In the case of using the signal amplitude as a diagnostic signal parameter, the 73 defects were detected. In the case of using the integral parameter $F b$, the 91 defects were detected. Therefore, the probability of detecting defects by the amplitude method was 0.73 in the experiment. The probability of detecting defects by the instantaneous frequency of the signal, which was determined by its unwrapped phase characteristic, was 0.91 .

\section{CONCLUSION}

The requirements to obtain the best mechanical, physical, chemical, and technological properties of materials, combined with low cost and weight, stimulates the process of creating new aircraft structural materials and expanding the range of existing ones. The significant variation in the physical properties of aircraft structural materials requires the improvement of testing methods and tools both at the stage of material creation and finished products. The results of non-destructive testing of materials and products depend not only on the used physical method but also on the algorithm of processing the signals and on choosing the most informative parameters and characteristics of them.

It is shown narrow-band electrical signals are generated during the implementation of the eddycurrent, ultrasonic and acoustic methods of NDT. The application of discrete Hilbert transform to such signals allows obtaining and performing the precise measurements of the amplitude, phase, and frequency characteristics of signals with localized in time perturbations caused by the heterogeneities of the structure and physicomechanical characteristics and parameters of materials and products.

Offered combining the discrete Hilbert signal transformation with the methods of deterministic and statistical phase measurements allows creating software and hardware of aviation structural materials that allow increasing the probability of detection of defects. Many given examples show that the proposed signal processing methodology enables the determination of new information signal parameters and characteristics in the NDT industry and upgrade the scope of known NDT methods for aircraft structural materials evaluation.

\section{REFERENCES}

[1] Ostash, O., Fedirko, V., Uchanin, V. Bychkov, S., Moliar, O., Semenets, O., Kravets, V. and Derecha, V., 2007, Fracture mechanics and strength of materials (in Ukrainian), Vol. 9. Strength and durability of airplane materials and structural elements (in Ukrainian), Lviv, Spolom.

[2] Sophian, A., Tian, G. Y., Taylor, D. and Rudlin, J., 2002, Design of a pulsed eddy current sensor for detection of defects in aircraft lap-joints, Sensors and Actuators, 101 (2002), pp. 92-98.

[3] Ostash, O., Uchanin, V., Semenets, O., Holovatyuk, Y., Kovalchuk, L. and Derecha, V., 2018, Evaluation of Aluminium Alloys Degradation in Aging Aircraft, Research in Nondestructive Evaluation, 29:3, pp. 156-166

[4] Kuts, Y., Monchenko, O., Bystra, I., and Oliinyk, Y., 2019, Phase method of ultrasonic pulse-echo thickness measurement of products made of structural materials (in Ukrainian), Interservise, Kyiv.

[5] Eremenko, V., Pereidenko, A. and Suslov, E., 2013, , Universal Journal of Engineering Science, Vol. 1 (3), pp. 95-109.

[6] Bendat, J. S. and Piersol, A. G., 2010, Random Data: Analysis and Measurement Procedures, Wiley, Hoboken, NJ.

[7] Lyons, R. G., 2004, Understanding digital signal processing, Upper Saddle River, A Prentice Hall PTR Publication.

[8] Mardia, K. V., and Jupp, P. E., 2000, Directional Statistics, Wiley, Hoboken, NJ.

[9] Fisher, N., 2000, Statistical analysis of circular data, Cambridge: Cambridge University Press, UK. 
[10] Kuts, Y., Protasov, A., Lysenko, I., Dugin, O., Bliznuk, O. and Uchanin V., 2017, IEEE First Ukraine Conference on Electrical and Computer Engineering, Kyiv, May 29 - June 2, pp. 826-829.

[11] Derhunov, O., Kuts, Y., Monchenko, O., Shengur, S. and Oliinyk, Y., 2018, Improvement of ultrasonic testing method for materials with significant attenuation, Eastern-European Journal of Enterprise Technologies, 1/9(91), pp. 54-61.

[12] Galagan, R., 2019, Theoretical foundations of ultrasonic non-destructive testing (in Ukrainian), Igor Sikorsky Kyiv Polytechnic Institute, Kyiv.

[13] Eremenko, V., Suslov, E., Protasov, A. and Pavlenko, Zh., 2016, Hilbert Transform Utilization for Additional Informative Features Receiving at the Pulsed Impedance Testing of Composite Materials, (in Ukrainian), KPI Science News, 1, pp. 117-123.

[14] Eremenko, V., Suslov, E., Protasov, A. and Lysenko, I., 2016, Using Hilbert Transform for Signal Processing in Mechanical Impedance Analysis, 19th World Conference on Non-Destructive Testing 2016, NDT.net Issue: 2016-07, pp. 1-8.

\title{
ZAAWANSOWANE METODY KONTROLI MATERIAŁÓW W STRUKTURACH STATKÓW POWIETRZNYCH
}

\begin{abstract}
Abstrakt
Samoloty, ich zespoły i jednostki muszą zapewniać wysoką trwałość i niezawodność oraz utrzymywać właściwości mechaniczne i technologiczne przez cały okres użytkowania statku powietrznego. Różne elementy konstrukcji lotniczych pracują pod obciążeniami mechanicznymi, w szerokim zakresie temperatur, z różnym stopniem narażenia na środowiska korozyjne. Materiały konstrukcyjne statków powietrznych różnią się właściwościami i wymagają różnych metod testowania w celu ich kontroli. W wielu metodach NDT stosowanych w testowaniu materiałów lotniczych sygnały, które mogą być badane stosowany jest model procesów wąskopasmowych. Znane metody ich przetwarzania koncentrują się na określeniu i analizie charakterystyk amplitudy sygnałów, ale zasoby informacyjne zawarte w charakterystyce fazowej nie są wykorzystywane. W artykule omówiono metodologię przetwarzania sygnału i określania charakterystyk fazowych w domenie czasowej. Opiera się on na kombinacji dyskretnej transformaty Hilberta oraz deterministycznych i statystycznych metod pomiaru fazy. W pracy podano przykłady zastosowania metodyki badań pulsacyjnych prądów wirowych materiałów i produktów przewodzących prąd. Ultradźwiękowy pomiar grubości wyrobów wykonanych z materiałów ma znaczne tłumienie ultradźwięków, wariant realizacji defektu impedancji akustycznej wykrywania wad wykonanych z materiałów kompozytowych. Przykłady pokazały, że proponowana metodologia przetwarzania sygnału umożliwia określenie nowych parametrów informacji i charakterystyk sygnału dla materiałów oraz rozszerza zakres znanych metod NDT.
\end{abstract}

Słowa kluczowe: metodologia przetwarzania sygnału, charakterystyka sygnału, parametry informacyjne, testowanie materiałów lotniczych. 